\title{
An Investigation into the Influence of Blended Learning on Oral English Proficiency of Senior High School Students
}

\author{
Li Xin $^{1} \&$ Zhao Zhongbao ${ }^{2}$ \\ ${ }^{1}$ Yue Yang Vocational and Technical College, China \\ ${ }^{2}$ Hunan Institute of Science and Technology, China \\ Correspondence: Zhao Zhongbao, 439 Xueyuan Road, Graduate School, Hunan Institute of Science and \\ Technology, Yueyang City, Hunan Province, China. E-mail: michaelzhao998@hotmail.com
}

Received: September 3, 2020

Accepted: December 4, 2020

Online Published: June 23, 2021

doi:10.5539/ies.v14n7p27

URL: https://doi.org/10.5539/ies.v14n7p27

\begin{abstract}
We advocate the in-depth integration of information technology and education in the digital age, and we also encourage teachers of all disciplines to actively carry out online and offline blended learning. This study attempts to use an empirical research to apply the Blended Learning to the oral English teaching in the first year of senior high school. A one-semester teaching experiment is conducted to explore whether there is a significant difference in the students' oral English proficiency between the experimental class and the controlled class. The major findings of the study are as follows: (1) There are significant differences of students' oral English proficiency before and after the experiment in the experimental class and the controlled class; (2) Blended learning can improve students' oral English proficiency, among which pronunciation and intonation, range and accuracy of vocabulary and fluency of language are the most significant ones, while the accuracy and complexity of grammatical structure are insignificant.
\end{abstract}

Keywords: oral English, teaching in senior high school, blended learning, oral English proficiency

\section{Introduction}

Blended Learning is a learning model that combines the advantages of traditional classroom learning and modern web-based learning. Supported by modern information technology, the extension of online learning expands the space of English teaching and learning, and the flexibility and interactivity of students' learning. In the English teaching practice, it not only fully reflects the initiative of students as the main body of learning, but also plays the leading role for teachers in the teaching process (He, 2004). Blended Learning is a deep reflection on constructivism theory to guide education and teaching practice.

The National English Curriculum Standards for General High School [NECSGHS] (2017 Edition), released in January 2018, puts forward that senior high school English teaching should meet the individual development needs of students in the basic teaching concept. We should pay attention to the application of modern information technology and enrich the learning resources of English courses (NECSGHS), 2018). Obviously, because students' consciousness in senior high school has been significantly enhanced, the English teaching should actively promote the deep integration of curriculum implementation and information education technology, and scientifically organize and carry out online and offline combined teaching under the background of modern information technology.

Judging from the current English education teaching situation in senior high school, the teaching requirements emphasized by the New Curriculum Standards clearly exceed the students' actual oral English proficiency. As for the main obstacles encountered by students in oral learning, the top three ones are the lack of opportunities and context for oral practice, lack of time and energy investment, and lack of motivation to learn (Zhang, Guo, Wu, \& Zhang, 2017). But when senior students enter the undergraduate colleges or vocational colleges, even enter the company to work or go abroad for further study, the cultivation of oral English expression skills needs to be highly valued. At present, the research on the application of blended learning in oral English teaching has achieved some results, but it is mainly aimed at the ESP and College English teaching. There are very few studies applied to oral English teaching in primary and middle schools. And the theoretical research is the mainstay, and there are few empirical studies. Moreover, when studying the students' oral English proficiency, they rarely carry out 
quantitative research from the students' pronunciation intonation, vocabulary level, grammatical knowledge and fluency of expression. With the new curriculum standards attaching importance to students' English language ability and the concept of Blended Learning in senior high school, it has laid an important theoretical foundation for the development of senior high school oral English Blended Learning research.

To sum up, the relevant researches on Blended Learning, oral English teaching and blended oral English teaching have all got some achievements at present. Among them, the research on technology application in blended teaching has got the most remarkable achievement which provides important reference value to the application research in subject teaching. Blended Learning is not only a theory or structure, but also a transformation of school teaching concepts in the country and even all over the world. The advantages of Blended Learning have brought some enlightenment to the ongoing education and teaching reform in our country. The New English Curriculum Standard emphasizes the scientific organization of online and offline blended teaching concepts is an important measure related to this reform. However, through searching the literature, it is found that the current research to the blended learning is mainly concentrated on the education teaching in college and university, and the research of English teaching in the basic education stage is still in its infancy, and the research literature is relatively not popular, especially in oral English teaching in senior high school.

\section{Research Design}

\subsection{Research Questions}

An experimental method in this study has been used to conduct the oral English teaching by combining online and offline learning in a semester, and the research tries to solve the following four problems:

1) How does Blended Learning affect the pronunciation and intonation of senior high school students' oral English?

2) How does Blended Learning affect the accuracy and complexity of the grammatical structure of senior high school students' oral English?

3) How does Blended Learning affect the vocabulary abundance and accuracy of senior high school students' oral English?

4) How does Blended Learning affect the fluency of senior high school students' oral English?

\subsection{Research Object}

In this study, two classes in the first grade of a senior high school were selected as the research object, and the subject were 60 senior high school students. The pre-test showed that the average oral scores of the two classes were respectively 72.16 and 72.08 , with a score difference of 0.08 . The independent sample $\mathrm{T}$ test result Sig (two-tailed) is 98 , which is more than 0.05 , indicating that the average oral scores of the two natural classes before the experiment are not significantly different, and can be determined as intact classes.

\subsection{Research Tools}

The experimental tools used in this research include oral test, oral test score scale, and questionnaire.

\subsection{Experimental Process}

The teaching design of the experimental class follows the blended English teaching concept and teaching mode, and the conventional teaching mode is adopted for the control class.

\subsubsection{The Blended Learning Design of Oral English Teaching}

\section{(1) The Design of Teaching Preparation}

The topic Unit1 School Life in Oxford High School English (Module 1) is selected. It is expected that students can broaden their knowledge and form their own opinions based on understanding the background knowledge of Chinese and British students' learning life in senior high school. And then students are able to create English conversations to train oral English expression skills and enhance language skills.

In order to achieve this teaching goal, the researcher chose a mini-lesson with the theme of The High School Life in $U K$, as well as some photos of learning life on some famous senior high school in China as online learning resources. At the same time, QQ groups, WeChat and other chat tools were created for teacher-student interaction.

(2) The Design of Classroom Learning

Compared with conventional teacher-centered classroom, blended learning is student-centered, which is consistent with the core concept of constructivist learning. The face-to-face learning classroom is mainly for students to show their achievements in online learning. Students achieve their oral output in the problem-oriented form and use 
activities as carriers. Some questions designed by the teacher such as:

Q1: What is A-Level?

Q2: If a student wants to study in world-class universities such as Oxford, Cambridge, Harvard and other famous schools, what marks are required to achieve?

Q3: What is divergent thinking?

Q4: Do you want to go to high school in England? Why?

By asking questions, students are provided with opportunities and platforms for oral output. At the same time, design a poster: What is your dream school life like? Please make a poster by writing some key words. Students finish this task in group, teacher gives necessary learning help and guidance, students share results and discuss issues, and finally students make self-evaluation and teacher gives comments and conduct real-time feedback.

\section{(3) The Design of Online Learning}

Online learning includes student self-directed learning and teacher-led learning. Students conduct learning autonomy through some platforms. For example, listening and speaking exercises have been designed in the Scallop Listening APP, which matches the Oxford High School Textbooks. These exercises include basic clearance training and direct college entrance examination training, which are closely connected with students' learning. The learning under the guidance of teachers is conducted under the guidance and supervision of teachers, which is mainly aimed at some students with poor academic ability. Teachers can interact with students through communication platforms such as E-mail, QQ and WeChat to guide and supervise some students' oral tasks finishing.

Students learn the mini-lesson The High School Life in UK and some photos about senior high school learning life and other resources online. When students encounter difficulties, they can discuss with classmates and teachers through chat tools, and the questions can also be collected for students to do brainstorming in class.

\section{(4) Learning Evaluation and Teaching Adjustment}

The evaluation of the blended learning classroom not only includes the students' knowledge learning, but also evaluates the students' teamwork ability and students' independent learning ability. The combination of formative evaluation and summative evaluation, as well as students' self-assessment and teachers' evaluation makes teachers and students more clearly aware of the achievements and deficiencies in the learning process. Teachers modify and adjust the learning plan according to the learning evaluation, and prepare for a new round of teaching.

\subsubsection{Experiment Implementation}

During the experiment, the researcher used the same textbook and different teaching modes to conduct the experiment. In the experimental class, a blended learning method combining online learning and offline face-to-face teaching is designed, and the control class uses the conventional face-to-face teaching mode. The experiment lasted one semester from September to January.

There are three differences in the teaching between the two intact classes. Firstly, there is no online learning in the control class, and the students do not learn materials such as mini-lessons and pictures online in advance. Secondly, the teaching activities in the control class are mainly that students follow teachers' reading to learn important English vocabulary and phrases, and memorize language expressions and express their views on the similarities and differences in Chinese and British senior high schools' learning life. The teaching in the experimental class is based on the language input before the class. The teaching and learning is mainly problem-oriented to guide students to express their opinions, and then complete the poster production in groups. After finishing the thinking and discussing, the representatives are invited to report on the results. Finally, students in the experimental class implement mutual evaluation and self-assessment during the learning process, while students in the control class only conduct teachers' evaluation. During the experiment, teachers should keep a record of the number of students' interactions and learning interest in the experimental class during online and offline learning. The experimental class and the control class conduct oral test every 3-4 weeks and collect a total of 5 times of data in a semester, all of which are submitted in the form of recording materials.

\section{Data Collection}

\subsection{Scoring and Analysis of Spoken Language}

A total of 300 spoken speech samples were collected before and after the experiment. The recording was clear and the answers were complete. There are respectively 30 students in the experimental class and the control class. 5 tests in both classes and 150 test samples in each class were collected. 


\section{(1) Speaking Score}

After collecting the samples for each oral test, the researcher and another English teacher will score for students according to the scoring criteria. The scoring uses a 5-point system, with 5 points for each of the item, which includes pronunciation and intonation, grammar, vocabulary and expressions. It is 25 points in each item after weighting and the full score is 100 points. Pronunciation and intonation item examines the authenticity of phonetic intonation; grammar item examines the accuracy and complexity of grammatical knowledge and structure; vocabulary item examines the richness and accuracy of vocabulary; oral expression item examines the fluency of expression.

In order to ensure the credibility of scoring the oral English test, this study uses a double scoring system. That means two teachers score for the oral English test. Before the formal test two teachers communicate and learn the scoring criteria, conduct small-scale tests and analyze student achievements to ensure consistent scoring. The Pearson correlation analysis coefficient of the double scoring in the experimental class was .87, which indicates that the two scorers have a linear relationship of positive correlation. The number of significance (two-tailed) is .000 , indicating that the probability of uncorrelation between the two scorers' rating variables is almost zero. And there is ** in the upper right of .87 , indicating that a significant level of 0.01 is reached. Therefore, there is a significant correlation between the two scorers, indicating that the oral test has good inter-rater reliability.

\section{(2) Statistics of Oral Scores}

The SPSS23.0 statistical software was used for independent sample $T$ test for the oral test scores in the experimental class and the control class, and the paired sample $\mathrm{T}$ test was performed for the four scores of pronunciation and intonation, vocabulary, grammar and fluency of the oral performance of the two classes.

\section{Results}

\subsection{Comparison of Oral Performance in Experimental and Control Classes}

Before the experiment, the average scores of the pre-test in the experimental class and control class were respectively 72.16 and 72.08 , with an average difference of 0.08 . During the teaching process, the average scores of the second to the fourth oral test in the experimental class were respectively 74.083,74.167, and 76.667, and the data showed an increasing trend, especially the fourth oral test score was very obvious. The minimum score has increased from 50 points in the pre-test to 60 points, and the maximum score has not changed. The average scores of the second to the fourth oral test in the control class were respectively $72.083,72.167,72.833$, the minimum score increased from 57.5 to 60 , and the maximum score was the same as before. That means that the oral performance of the students in the control class is also gradually improving, but the increase is not obvious.

Table 1. Description statistics of test2-test4 score in two classes

\begin{tabular}{cccccc}
\hline & Number & Minimum & Maximum & Average & Standard Deviation \\
\hline EC Test2 & 30 & 52.5 & 97.5 & 74.083 & 14.2859 \\
EC Test3 & 30 & 52.5 & 97.5 & 74.167 & 14.9328 \\
EC Test4 & 30 & 60.0 & 97.5 & 76.667 & 13.3477 \\
CC Test2 & 30 & 57.5 & 95.0 & 72.083 & 10.6691 \\
CC Test3 & 30 & 50.0 & 97.5 & 72.167 & 12.6752 \\
CC Test4 & 30 & 60.0 & 95.0 & 72.833 & 10.4579 \\
Number of Valid Cases (in columns) & 30 & & & & \\
\hline
\end{tabular}

Note. $\mathrm{EC}=$ Experimental Class; $\mathrm{CC}=$ Controlled Class.

At the end of the semester, the average scores of the post-test in the experimental and control classes were respectively 79.0 and 73.0, the average difference was 6 points, and the Sig (two-tailed) of independent sample T test is .048 , less than 0.05 , which shows that the two variables of the post-test scores were significantly different. The paired sample $\mathrm{T}$ test showed that the average score in the experimental class before and after the experiment increased by 6.83 , and the Sig (two-tailed) is .00, less than 0.05 , which expresses the difference was significant. The average score before and after the experiment in the control class increased by 0.92 , and the Sig (two-tailed) is .00 , less than 0.05 , which stands the difference was also significant. It can be seen that after a semester of English learning, students' oral skills in the experimental and control classes have improved significantly, but in comparison, the progress made by the students in the control class is significantly smaller than that in the experimental class. Through blended learning, students' oral proficiency in the experimental class has improved 
significantly, while students' oral performance in the control class has also improved.

Table 2. Statistics of post-test in experimental class and control class

\begin{tabular}{cccccc}
\hline & Class & Number & Mean & Standard Deviation & Standard Error Mean \\
\hline \multirow{2}{*}{ post-test } & EC & 30 & 79.000 & 11.991 & 2.189 \\
& CC & 30 & 73.000 & 11.013 & 2.010 \\
\hline
\end{tabular}

Table 3. Independent sample t test for post-test results in experimental class and control class

\begin{tabular}{|c|c|c|c|c|c|c|c|c|c|c|}
\hline & & & $\begin{array}{l}\text { Variance } \\
\text { alence Test }\end{array}$ & \multicolumn{7}{|c|}{ Mean Equivalence T Test } \\
\hline & & \multirow{2}{*}{$\mathrm{F}$} & \multirow{2}{*}{ Significance } & \multirow{2}{*}{$\mathrm{t}$} & \multirow{2}{*}{ Freedom } & \multirow{2}{*}{$\operatorname{Sig}($ two-tailed) } & \multirow{2}{*}{$\begin{array}{c}\text { Mean } \\
\text { Difference }\end{array}$} & \multirow{2}{*}{$\begin{array}{c}\text { Standard } \\
\text { Error }\end{array}$} & \multicolumn{2}{|c|}{$\begin{array}{c}95 \% \text { Confidence } \\
\text { Interval } \\
\end{array}$} \\
\hline & & & & & & & & & $\begin{array}{l}\text { Lower } \\
\text { Limit }\end{array}$ & $\begin{array}{l}\text { Upper } \\
\text { Limit }\end{array}$ \\
\hline \multirow{2}{*}{ Post-test } & $\begin{array}{c}\text { assumes } \\
\text { equal } \\
\text { variance }\end{array}$ & 1.118 & .295 & 2.018 & 58 & .048 & 6.000 & 2.972 & .0497 & 11.950 \\
\hline & $\begin{array}{c}\text { not assume } \\
\text { equal } \\
\text { variance }\end{array}$ & & & 2.018 & 57.585 & .048 & 6.000 & 2.972 & .0488 & 11.951 \\
\hline
\end{tabular}

The description statistics of the pre-test and post-test results in the experimental class (Table 4) show that the average oral proficiency is 72.167 and 79.000 , with an increase of 6.833 points. The paired sample T test (Table 5) shows that the significance probability Sig (two-tailed) of the two variables is .00 , which is less than 0.05 , indicating that the test results is significantly different in this variable. In addition, the $95 \%$ confidence interval of the difference is -8.512 to -5.153 , and 0 is not included, which also indicates that the average difference is significant. It can be seen that the students in the experimental class have significantly improved their oral English in the blended learning.

Table 4. Statistics of the pre-test and post-test score in the experimental class

\begin{tabular}{cccccc}
\hline & & Mean & Number & Standard Deviation & Standard Error Mean \\
\hline \multirow{2}{*}{ EC } & Pre-test & 72.167 & 30 & 15.0535 & 2.7484 \\
& Post-test & 79.000 & 30 & 11.9914 & 2.1893 \\
\hline
\end{tabular}

Table 5. Paired Sample T Test for Pre-test and post-test in Experimental Class

\begin{tabular}{|c|c|c|c|c|c|c|c|c|c|}
\hline & & \multicolumn{5}{|c|}{ Pairing Difference } & \multirow{4}{*}{$\mathrm{T}$} & \multirow{4}{*}{ Freedom } & \multirow{4}{*}{ Sig (Two-tailed) } \\
\hline & & \multirow{3}{*}{ Mean } & \multirow{3}{*}{$\begin{array}{l}\text { Standard } \\
\text { Deviation }\end{array}$} & \multirow{3}{*}{$\begin{array}{c}\text { Standard Error } \\
\text { Mean }\end{array}$} & \multicolumn{2}{|c|}{$\begin{array}{c}95 \% \text { Confidence } \\
\text { Interval }\end{array}$} & & & \\
\hline & & & & & Lower & Upper & & & \\
\hline & & & & & Limit & Limit & & & \\
\hline EC & $\begin{array}{c}\text { Pre-test } \\
\text { \&post-test }\end{array}$ & -6.833 & 4.497 & .821 & -8.512 & -5.153 & -8.321 & 29 & .000 \\
\hline
\end{tabular}

From the data in Table 1 to Table 5, we can see that before the experiment, the average scores in the experimental and control classes were respectively 72.167 and 72.083 , and the average difference was 0.084 . After the experiment, the average scores in the experimental and control classes were respectively 79.0 and 73 , the average difference was 6 points, and the independent sample T test Sig (two-tailed) is .048 , which is less than 0.05 , showing that the two variables of the post-test results were significantly different. The paired sample $\mathrm{T}$ test showed that the average score in the experimental class increased by 6.833 , Sig (two-tailed) is .00 , less than 0.05 , which indicates the difference was significant. The average score between the pre-test and post-test in the control class increased by 0.917 , Sig (two-tailed) is .00 , which is less than 0.050 , the difference was also significant. It can be seen that after a semester of English learning, students' oral English proficiency in the experimental and control 
classes have improved significantly, but in comparison, the progress made by the students in the control class is significantly smaller than that in the experimental class. After blended learning, students' oral performance in the experimental class has improved significantly. While students' oral English level in the control class also improved, but the progress was relatively small.

\subsection{Comparison of Students' Oral Scores in the Experimental Class between Pre-test and post-test}

The average score between the pre-test and post-test in the control class increased by 0.92 . Although $T$ test showed significant improvement, the average score increased very little, so no comparative analysis of each item result was done. However, the oral performance in the experimental class was improved by 6.83 points. In order to understand the progress of the students' pronunciation and intonation, the accuracy and complexity of the grammatical structure, the range and accuracy of the vocabulary, and the fluency of expression, the researcher analyzed the paired scores of pre-test and post-test in the experimental class to further test the students' oral development proficiency in the blended learning mode.

It is understood that the overall level of students' spoken language between the pre-test and post-test is significantly different, but the sub-scores show different result. Among them, the pronunciation and intonation, the range and accuracy of vocabulary and the fluency of expression have significantly improved. The Sig (two-tailed) is respectively $.00, .01, .00$, and all are less than 0.05 . At the same time, the average difference $95 \%$ confidence interval does not contain 0 . But to the accuracy and complexity of the grammatical structure sample the Sig (two-tailed) is .42 , which is less than 0.05 , and the $95 \%$ confidence interval contains 0 , showing that there is no significant difference in the students' grammatical structure learning, and so the student's progress is not obvious.

Table 6. Comparison of paired scores of pre-test and post-test in the experimental class

\begin{tabular}{|c|c|c|c|c|c|c|c|c|}
\hline & & \multirow{4}{*}{$\begin{array}{c}\text { Average } \\
\text { Score }\end{array}$} & \multicolumn{2}{|r|}{$\mathrm{EC} n$} & & \multirow{4}{*}{$\mathrm{t}$} & \multirow{4}{*}{$\begin{array}{l}\text { Degrees of } \\
\text { Freedom }\end{array}$} & \multirow{4}{*}{ Sig (two-tailed) } \\
\hline & & & \multirow{3}{*}{ Standard } & \multicolumn{2}{|c|}{$95 \%$ Confidence Interval } & & & \\
\hline & & & & Lower & Upper & & & \\
\hline & & & & Limit & Limit & & & \\
\hline \multirow{3}{*}{$\begin{array}{c}\text { Pronunciation } \\
\text { and } \\
\text { Intonation }\end{array}$} & pre-test & 19.17 & 3.3 & \multirow{3}{*}{-2.6} & \multirow{3}{*}{-1.1} & \multirow{3}{*}{-5.1} & \multirow{3}{*}{29} & \multirow{3}{*}{.00} \\
\hline & post-test & 21.08 & 3.6 & & & & & \\
\hline & & & & & & & & \\
\hline \multirow{2}{*}{ Grammar } & pre-test & 17.08 & 4.0 & \multirow{2}{*}{-.87} & \multirow{2}{*}{.37} & \multirow{2}{*}{-.83} & \multirow{2}{*}{29} & \multirow{2}{*}{.42} \\
\hline & post-test & 17.33 & 4.2 & & & & & \\
\hline \multirow{2}{*}{ Vocabulary } & pre-test & 17.83 & 4.4 & \multirow{2}{*}{-3.4} & \multirow{2}{*}{-.41} & \multirow{2}{*}{-2.6} & \multirow{2}{*}{29} & \multirow{2}{*}{.01} \\
\hline & post-test & 19.75 & 5.0 & & & & & \\
\hline \multirow{2}{*}{ Fluency } & pre-test & 17.75 & 4.4 & \multirow{2}{*}{-2.97} & \multirow{2}{*}{-1.36} & \multirow{2}{*}{-5.51} & \multirow{2}{*}{29} & \multirow{2}{*}{.00} \\
\hline & post-test & 19.91 & 3.1 & & & & & \\
\hline
\end{tabular}

\section{Discussion}

The experimental results show that the students in the experimental class have made significant progress in spoken English, especially the students' pronunciation and intonation, fluency of expression, and the range and accuracy of vocabulary. These three items have different levels of significant improvement. There are many reasons for the improvement of students' oral English level, which are generally summarized as internal factors and external factors. About internal factors, there is students' emotion, language foundation, psychology, and attaching importance to English learning and etc. External factors include the learning environment, the number of language exercises and etc. Blended Learning has played a certain role in improving students' oral English from both internal and external factors. For example, the provided online and offline learning environment allows students to learn and master English knowledge in a rich and diverse language environment; the learning resources and learning methods have stimulated students' interest in learning and etc.

\subsection{The Effect of Blended Learning on High School Students' Oral English Pronunciation and Intonation,} Vocabulary and Fluency

Based on the basic viewpoints of Constructivist Learning Theory proposed by Piaget and the understanding of blended learning concepts and mode in the literature review, we can see that constructivist learning theory has important guiding significance for the implementation of blended learning mode. As we know Constructivist learning theory emphasizes that learning is a learner-centered process, and students actively construct knowledge 
meaning (Piaget, 1970). It also emphasizes the idea of taking students as the main body and teachers as the leading factor, while the Blended Learning is also a student-centered and problem-oriented mode. When conducting blended learning teachers should give guidance and supervision and focus on the cultivation of students' concept of independent inquiry and active discovery. In blended learning, when teachers guide, organize and monitor the whole class online, students enter certain learning situations in the online environment, or explore autonomously or collaboratively to cultivate autonomous learning skills. Teachers design valuable discussion questions related to the unit topic for students. Students focus on problem-oriented learning, actively think and explore, and then learn knowledge and get improved. In the offline learning, students learn face to face. Some learning activities designed by teachers are used as carriers to create opportunities and platforms for students. Teachers attach enough importance to students' language expression and learning exchanges, and motivate students' learning initiative. In the online and offline learning process, students build knowledge based on their own experience, driven by tasks, and conduct oral expression and high-level thinking activities under the guidance of teachers. Experiments show that in this learning process, students' vocabulary and language and phonetic knowledge can be better improved.

The second theoretical basis is the Mastery Learning, proposed by American contemporary psychologist Benjamin Bloom. The Mastery Learning and Blended Learning concepts are not the same but they are similar. The theory emphasizes that students' cognitive structure is the premise of mastering learning, and students' positive emotional characteristics are the internal factors of mastery learning. Moreover, teachers should pay much attention to the formative evaluation (Bloom, 2011).

In blended English learning, students conduct topic-related knowledge learning online before class, and the learning content is connected with the students' existing cognitive structure, which provides the necessary prerequisite for mastering learning. Online learning resources are directly perceived and interesting, and students can learn at any time or any place. Fragment and live knowledge is helpful to stimulate high school students' enthusiasm for learning. At the same time, teachers' attention and evaluation online and offline can stimulate students' learning initiative, which can make students have positive emotional characteristics. Formative evaluations such as online and offline quizzes and timely feedback belong to the teaching feedback-correction system, which is the core of learning. In the blended learning mode, effective teaching evaluation is used to promote students' effective learning.

For Chinese English learners, phonetic imitation training can directly improve the learner's phonetic ability (Wu \& Zhao, 2013). In blended learning, teachers provide students with audio-visual materials from native English in the United Kingdom and the United States. Students use imitation training to improve the recognition of speech and their pronunciation and intonation level. The improvement of pronunciation and intonation level enables students to increase self-confidence. To a certain extent, it can reduce students' oral anxiety and form a sense of speech ability, thereby further improve students' pronunciation and intonation level, which is a hidden infinite effective cycle.

The increase in students' vocabulary is closely related to the variety of materials in the blended learning, and it is also closely related to the type of task activities carried out on a certain topic in the classroom. Students use verb collocations and phrases to answer questions and express ideas in post-test, such as in charge of, be ignorant of, add up to, etc. While students in the control class still use simple words such as be able to, do, increase, etc. That can explain that the students in the experimental class have accumulated more advanced vocabulary after learning through multiple materials in the blended learning. The increase in vocabulary has an important impact on the improvement of spoken language. As Lehmann said, vocabulary knowledge has a strong correlation with reading, listening, speaking and language ability, so the improvement of vocabulary is closely related to the students' spoken language (Lehmann, 2007).

The pairing sample data of each item shows that students' fluency in language expression is the most significant. The improvement of language fluency is directly related to the improvement of students' self-confidence, the increase of vocabulary and cultural semantics, the increase of context, etc. (Oppenheim, 2000; Zhang, 1999). In blended learning, students learn English from a variety of materials, which is essential to broaden their knowledge. They practice oral English through task activities, constantly trial and error, and achieve oral output. The textbooks are materials in real life, and there are also network resources in the virtual environment. Task activities include self-test questions and learning task lists in a virtual environment, as well as activities such as dialogue practice, role-play, and poster making in the classroom. Students master language points, words and useful expressions by learning rich materials, and repeat topic expressions in various forms of activities (Zhou, 2004). They become more and more proficient in the required vocabulary and answering framework, and more familiar with content and forms they need complete. Therefore, students can calmly challenge a variety of oral output tasks. In this process, the fluency of language expression has been improved. The improvement of students' contextual 
knowledge, the increase of vocabulary, the improvement of pronunciation and intonation level and the increasing self-confidence all contribute to the improvement of students' fluency in English expression. The cohesion and repeated practice of online and offline activities in the blended learning also verify the results of fluency of spoken language output positively affected by task repetition proposed by some relevant scholars.

\subsection{The Effect of Blended Learning to Senior High School Students' Oral English Grammar Learning}

The overall speaking level of the students in the experimental class has improved significantly, but the data shows that the average difference between the accuracy and complexity of the students' grammatical structure and progress is 0.25 . The Sig (two-tailed) is .415 , which is more than 0.05 , indicating no significant progress. Some studies have shown that students' grammatical errors in spoken English output not only involve a lot of factors, but also are widely distributed. The students' learning grammar knowledge is affected by internal and external factors, such as the interference of mother language thinking, the students themselves do not pay enough attention to grammar learning, and there is no active and enough input, etc. The internal and external factors of blended learning mainly include the following four points. Firstly, the learning resources provided by teachers are not highly related to grammar learning, and lack of grammar practice. Students have not been trained in grammar knowledge in course learning, so grammar learning has not achieved new breakthrough. Secondly, when using sentences, the teacher did not correct the students' grammatical errors in time, and the students did not know what the correct English sentences should look like, so that the students lacked quality grammatical knowledge exercises in language learning. Thirdly, since most students' fluency in language expression is the most obvious, it may be that students take advantage of a large number of phrases and scattered words to express their ideas at the expense of the accuracy and complexity of grammatical structure in order to take care of the fluency of oral expression. So that the data of the grammatical structure item obtained during the test is not significant. In fact, this is actually a common phenomenon in the oral test. Some students did use some scattered notional words to express their views, and did not use a complete sentence. So it is impossible for them to use some difficult or high-level sentences such as clauses or non-predicate verbs to express opinions. Finally, because the acquisition of grammatical rules is a slow and long learning process, short-term learning will not have a significant impact on students' mastering grammatical accuracy and complexity. However, grammar teaching is still one of the important modules that cannot be ignored in English teaching, especially at the stage of elementary and middle schools, when students learn the English basic knowledge. Although English teaching has always emphasized the importance of oral and written communication, the grammatical knowledge framework is the basis and necessary system for all forms of communication (Liu \& Fang, 2005). If you do not have a solid and systematic knowledge of grammar, the English sentences and essays spoken or written are all chaotic and not correct. Therefore, whether it is online learning or offline learning, teachers should emphasize the position and value of grammar knowledge in oral learning, strengthen the teaching of grammar knowledge, and urge students to master and proficiently use grammar.

\section{Conclusion}

The study of oral English learning is a long-term process. In this process, students will continue to be affected by favorable and unfavorable effects from family environment, cultural differences, psychological and social environment, etc. At the same time, oral English learning is also related to learning motivation, learning strategies and autonomous learning ability $(\mathrm{Ni}, 2010)$, which increase the difficulty of oral learning and make oral research a complex and challenging job. Due to limited energy and material resources, the sample size selected in this study is not large, and the effectiveness of the blended learning is only explained by the data of the students' oral level changes in a semester. So the limitation is obvious. However, applying the blended learning mode to the study of oral English teaching in senior high school will undoubtedly contribute to the enrichment of the horizontal and vertical research of oral teaching, and it is also an important exploration of the New Curriculum Standards emphasizing the cultivation of students' learning ability and language ability teaching practice.

\section{Acknowledgments}

This article was funded by Hunan Social Science Foundation, Project Number: 19YBA175 and Project of Scientific planning of Education in Hunan Province during the 13th five-year plan, Project Number: XJK20BZY043.

\section{References}

Bloom, S. B. (2011). Mastery Learning in the Science Classroom, Success for Every Student. Virginia: National Science Teachers Association Press.

He, K. (2004). Looking at the New Development of Educational Technology Theory from the Perspective of 
Blended Learning (Part 2) (Vol. 4, pp. 10-15). China Audio-visual Education.

Lehmann, M. (2007). Is International or Incidental Vocabulary Learning More Effective? (Vol. 3, pp. 23-28). The International Journal of Foreign Language Teaching.

Liu, M., \& Fang, L. (2005). The Influence of Grammatical Factors on College Students' Spoken English (pp.90-95). Tsinghua University Education Research (S1).

Ministry of Education. (2018). National English Curriculum Standards for General High School (2017 ed.). Beijing: People's Education Press.

Ni, Q. (2010). Empirical Research on the Correlation of College English Learning Motivation, Learning Strategies and Autonomous Learning Ability (Vol. 3, pp. 30-35). Foreign Language Community.

Oppenheim, AV. (2000). The Importance of Recurrent Sequences for Nonnative Speaker Fluency and Cognition. In H. Riggenbach (Ed.), Perspective on Fluency (pp. 220-242). Arbor: University of Michigan Press. .

Piaget, J. (1970). Structuralism. New York, NY: Basic Books.

Wu, R., \& Zhao, C. (2013). The Effect of Phonetic Intonation Imitation Training on Spoken Anxiety of Chinese English Learners(Vol. 5, pp. 54-58). Journal of PLA University of Foreign Languages.

Zhang, W. (1999). Theoretical Model of Fluency Development in Second Language (Vol. 2, pp. 205-217). Modern Foreign Languages.

Zhang, W., Guo, Q., Wu, S., \& Zhang, H. (2017). My Country's English Teaching Status and Reform Suggestions-Based on the Current Situation and Needs Survey of Foreign Language Ability Assessment (Vol. 6, pp. 18-26). Chinese Foreign Languages.

Zhou, D. (2004). The Effect of the Number of Exercises on the Retelling of the Story (Vol. 5, pp. 41-45). Journal of the PLA College of Foreign Languages.

\section{Copyrights}

Copyright for this article is retained by the author(s), with first publication rights granted to the journal.

This is an open-access article distributed under the terms and conditions of the Creative Commons Attribution license (http://creativecommons.org/licenses/by/4.0/). 